\title{
Sweet Cherry (Prunus avium L.) and Peach (Prunus persica L.) Phenological Growth Stages According to BBCH Scale
}

\author{
Tabita-Teodora LISANDRU ${ }^{1}$, Adrian FÜSTÖS ${ }^{1}$, Viorel MITRE ${ }^{1 *}$, Adelina DUMITRAS ${ }^{1}$ \\ ${ }^{1}$ University of Agricultural Sciences and Veterinary Medicine, Cluj-Napoca, Romania. \\ *)Corresponding author, e-mail: mitreviorel@yahoo.com
}

BulletinUASVM Horticulture 74(1) / 2017

Print ISSN 1843-5254, Electronic ISSN 1843-5394

DOI:10.15835/buasvmcn-hort:12361

\begin{abstract}
This study gives a detailed description of the stages of stone fruits growth (Prunus avium L. and Prunus persica L.), according to the BBCH (Biologische Bundesantalt, Bundessortenamt und Chemische Industrie) scale, in the environmental conditions of Cluj-Napoca area. Phenological data were collected from 4 years old trees of Prunus avium L. and Prunus persica L. cultivars. The development stage of each organ was recorded during two growing seasons (2015-2016). Comparing the results it can be observed that there are some diffecences between cultivares development during two growing seasons, fact that influences the correct timing of orchard management.
\end{abstract}

Keywords: BBCH scale, climate change, phenology, stone fruits

\section{Introduction}

In the last decades, observing and understanding plant phenology has an important role in the context of climate change. Phenological transformations and fruit set problems are recognized in many fruit growing areas as a result of global warming effect on plant reproduction (Hedhly et al., 2009; Hedhly, 2011). Stone fruits, as sweet cherry and peach, are known as well adapted species in temperate regions with mild winters. Recent interest concentrate on expanding the range of ripening times in order to get profitable fruit offseason (Fadón, 2015). Changes in the timing of the phenophases of fruit trees have a great economical importance because it has a direct impact on fruit production (Chmielewski, 2004), fact that shows the importance of recognizing fruit trees phenology. The main purpose of studying phenology is to determine the periodicity in the life-cycle events of crops and to use the findings in agronomical management (Wei et al, 2013). Bleiholder et al. developed in 1989 a two-digit decimal coding system for angiosperms, the
BBCH-scale.The extended BBCH scale is a system for uniform encoding of plants phenologically growth stages (Meier, 1997).

\section{Aims and objectives}

The aim of this study is to present and detail descriptions of phenological growth stages of stone fruits, Prunus avium L. and Prunus persica L., according to the BBCH code, in the environmental conditions of Cluj-Napoca area, and to contribute to the standardization of phenology research regarding sweet cherry and peach.

\section{Materials and methods}

The study was carried out on the experimental station of the University of Agricultural Sciences and Veterinary Medicine from Cluj-Napoca (Romania). Cluj-Napoca city has a continental climate, characterized by warm and dry summers and cold winters.

Data were collected from 4 years old healty trees, irrigated and fertilized, of Prunus avium L. cvs. 'Karina', 'Summit', 'Sunburst' and 
Tab. 1. Phenological growth stages of Prunus avium L.'Karina' variety and Prunus persica L., 'Champion' variety according to BBCH code

\begin{tabular}{c|ccc}
\hline Phenological stages & $\begin{array}{c}\text { Photo ID of 'Karina' } \\
\text { variety }\end{array}$ & $\begin{array}{c}\text { Photo ID of 'Champion' } \\
\text { variety }\end{array}$ & BBCH code \\
\hline Dormancy & A1 & A1 & 00 \\
\hline Beginning of bud swelling & A2 & A2 & 01 \\
\hline First leaves unfolded & C & B2 & 11 \\
\hline First leaves fully expanded & D1 & - & 19 \\
\hline Inflorescence enclosed & B & - & 54 \\
\hline Single flower buds visible & B & - & 55 \\
\hline Most flowers with petals forming a hollow ball & C & B2 & 59 \\
\hline Full flowering & - & C & 65 \\
\hline End of flowering & D1 & D & 72 \\
\hline Sepals beginning to fall & D2 & E & 75 \\
\hline Fruit about half final size & E & - & 78 \\
\hline Fruit about 80\% of final size & F & F & 81 \\
\hline Beginning of fruit colouring & G & &
\end{tabular}

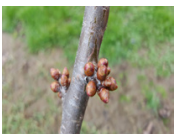

A1 00

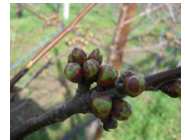

A2 01

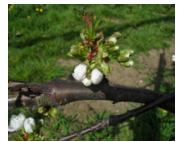

B 54/55

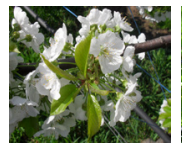

C 59/11



$\mathrm{D} 169 / 19$

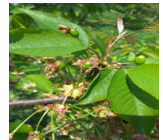

D2 72

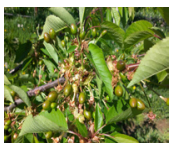

E 75

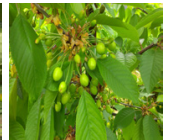

F 78

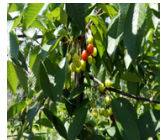

G 81

Fig.1. Phenological growth stages of cherry (Prunus avium L.) according to the BBCH scale, Karina variety

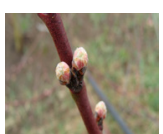

A1 00

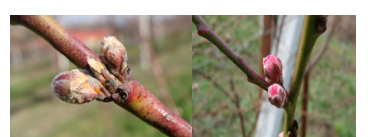

A2 01

A3 55

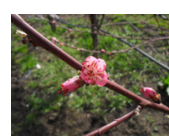

B1 57

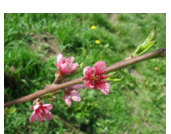

B2 $65 / 11$



C 69

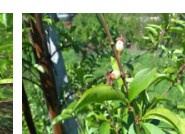

D 72



E 75
F 81

Fig.2. Phenological growth stages of peach (Prunus persica L.) according to the BBCH scale, Champion variety

Prunus persica L. cvs. 'Champion', 'Suncrest', 'Wassemberger'. The cultivars have been randomly selected. Observations of the phenological stages were made weekly, during two growing seasons (2015-2016). Photographs of each stage were taken to illustrate the reproductive development of stone fruits and to compare the cultivars between them to check the probable differences between them in their development during the growing seasons. Eight main growth stages are described for bud, leaf, shoot development, inflorescence emergence, flowering, fruit development and fruit maturity. Principal growth stage begin with bud development (stage 0 ) and end with maturity of fruit and seed (stage 8). Vegetative growth it is described by bud development (stage 0 ), leaf development (stage 1) and shoot development (stage 2). The next two stages are describing inflorescence emergence (stage 5) and flowering (stage 6). The last two growth stages are related to fruit development (stage 7) and fruit maturity and seed (stage 8).

\section{Results and discussion}

Phenological growth stages embrace the entire year cycle of Prunus avium L. (Fig.1) and Prunus persica L. (Fig.2), starting with stage 0 (bud development) and ending with stage 8 (fruit maturity). Eight growth stages of the BBCH scale from a total of ten are covered in case of both species (Tab.1). 
Tab. 2. Comparison of phenological stages between Prunus avium L. and Prunus persica L. cultivars, in two growing seasons (2015-2016)

\begin{tabular}{|c|c|c|c|c|c|c|}
\hline \multicolumn{7}{|c|}{ Year 2015} \\
\hline $\begin{array}{c}\text { Sweet cherry and } \\
\text { peach varieties }\end{array}$ & $\begin{array}{c}\text { Bud } \\
\text { development }\end{array}$ & $\begin{array}{c}\text { Leaf } \\
\text { development }\end{array}$ & $\begin{array}{l}\text { Inflorescence } \\
\text { emergence }\end{array}$ & Flowering & $\begin{array}{c}\text { Fruit } \\
\text { development }\end{array}$ & $\begin{array}{c}\text { Fruit } \\
\text { maturity }\end{array}$ \\
\hline 'Karina' & 23.03 & 20.04 & 20.04 & 30.04 & 05.05 & 07.07 \\
\hline 'Summit' & 23.03 & 14.04 & 20.04 & 30.04 & 05.05 & 02.07 \\
\hline 'Sunburst' & 23.03 & 20.04 & 20.04 & 30.04 & 05.05 & 02.07 \\
\hline 'Champion' & 28.03 & 14.04 & 20.04 & 30.04 & 05.05 & 23.08 \\
\hline 'Suncrest' & 23.03 & 14.04 & 14.04 & 30.04 & 05.05 & 19.07 \\
\hline 'Wassemberger' & 28.03 & 14.04 & 20.04 & 30.04 & 05.05 & 28.07 \\
\hline \multicolumn{7}{|c|}{ Year 2016} \\
\hline 'Karina' & 17.03 & 13.04 & 07.04 & 13.04 & 27.04 & 29.06 \\
\hline 'Summit' & 17.03 & 07.04 & 07.04 & 13.04 & 27.04 & 08.06 \\
\hline 'Sunburst' & 17.03 & 13.04 & 07.04 & 13.04 & 27.04 & 08.06 \\
\hline 'Champion' & 24.03 & 07.04 & 07.04 & 13.04 & 27.04 & 18.08 \\
\hline 'Suncrest' & 17.03 & 07.04 & 24.03 & 31.03 & 27.04 & 14.07 \\
\hline 'Wassemberger' & 24.03 & 07.04 & 07.04 & 13.04 & 27.04 & 20.07 \\
\hline
\end{tabular}

The results regarding the differences between Prunus avium L. and Prunus persica L. cultivars are presented in Tab. 2.

\section{Conclusion}

The phenological enlargement of stone fruits could improve the quality of fruits by providing informations about evolution of the cultivares, disease and pest management, irrigation, flower thinning, fertilizer effectiveness under the environmental conditions of Cluj-Napoca region. An accurate understanding of fruit trees phonological role it is essential for orchard management and could determin adaptation of species and cultivares to specific conditions. The results obtained also contribute to the standardization of phenology research regarding sweet cherry and peach.

\section{REFERENCES}

Bleiholder H, Langelüddeke P, Stauss R, (1989). Einheitliche Codierung der phänologischen Stadien bei. Kultur-und Schadpflanzen-Gesunde Pflanzen 41, 381-384.

Chmielewski FM, Müller A, Bruns E (2004). Climate changes and trends in phenology of fruit trees and field crops in Germany, 1961-2000, Agricultural and Forest Meteorology $12169-78$.

Fadóna E, Herreroa M, Rodrigob J (2015). Flower development in sweet cherry framed in the BBCH scale, Scientia Horticulturae 192 141-147

Hedhly A (2011). Sensitivity of flowering plant gametophytes to temperature fluctuations. Environ. Exp. Bot. 74, 9-16, http://dx.doi.org/10.1016/j.envexpbot

Hedhly A, Hormaza JI, Herrero M (2009). Global warming and sexual plantreproduction. Trends Plant Sci. 14, 30-36, http://dx.doi.org/10.1016/j.tplants

Meier U (1997). Growth Stages of Mono- and Dicotyledonous Plants. BlackwellScience, New York, NY.

Weia YZ, Zhangb HN, Lia WC, Xiea JH, Wanga YC, Liua LQ Shia SY (2013). Phenological growth stages of lychee (Litchi chinensis Sonn.) using theextended BBCH-scale, Scientia Horticulturae 161 273-277. 